\title{
Enhancement of Visible Light-Responsive Photocatalytic Efficiency by Using a Laccaic Acid-Modified Titanium Dioxide Photocatalyst
}

\author{
Montri Aiempanakit, ${ }^{a}$ Jariyaporn Sangkaworn, ${ }^{b}$ Nattawan Worawannotai, ${ }^{b}$ \\ Kritapas Laohhasurayotin, ${ }^{c}$ Weerachai Sangchay, ${ }^{d}$ Sakchai Laksee ${ }^{e}$ and \\ Cheewita Suwanchawalit ${ }^{\odot * b}$
}

\author{
${ }^{a}$ Department of Physics, Faculty of Science, Silpakorn University, 73000 Nakhon Pathom, Thailand \\ ${ }^{b}$ Department of Chemistry, Faculty of Science, Silpakorn University, 73000 Nakhon Pathom, Thailand \\ ${ }^{c}$ National Nanotechnology Center (NANOTEC), \\ National Science and Technology Development Agency (NSTDA), 111 Thailand Science Park, \\ Phahonyothin Road, Khlong Nueng, Khlong Luang, 12120 Pathum Thani, Thailand \\ ${ }^{d}$ Faculty of Industrial Technology, Songkhla Rajabhat University, 90000 Songkhla, Thailand \\ ${ }^{e}$ Nuclear Technology Research and Development Center, \\ Thailand Institute of Nuclear Technology (Public Organization), 26120 Nakhon Nayok, Thailand
}

\begin{abstract}
In this study, a laccaic acid-modified $\mathrm{TiO}_{2}$ photocatalyst $\left(\mathrm{Lac}-\mathrm{TiO}_{2}\right)$ was prepared via an impregnation method with $0.50,1.00,2.50$, and $5.00 \mathrm{wt} . \%$ laccaic acid. The products' physical properties were examined through X-ray powder diffraction (XRD), field emission scanning electron microscopy (FE-SEM), X-ray photoemission spectroscopy (XPS), UV-Vis diffused reflectance spectroscopy (DRS), Fourier-transform infrared spectroscopy (FTIR), nitrogen adsorption/desorption, and photoluminescence (PL) spectroscopy. A possible photocatalytic mechanism was also proposed. XRD patterns revealed the anatase phase of $\mathrm{TiO}_{2}$ and $\mathrm{Lac}^{-\mathrm{TiO}_{2}}$

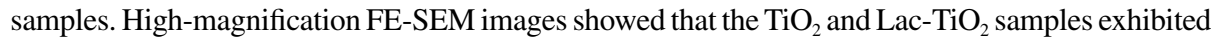
spherical-like structures. XPS results complementarily confirmed the presence of $\mathrm{Ti}, \mathrm{O}$, and $\mathrm{C}$ as the main elements of the $\mathrm{Lac}_{-} \mathrm{TiO}_{2}$ samples. Interestingly, the DRS spectra of the $\mathrm{Lac}^{-\mathrm{TiO}_{2}}$ samples extended into the visible region. FTIR spectra presented the characteristic bands of $\mathrm{TiO}_{2}$ and hydroxyl groups on the $\mathrm{TiO}_{2}$ surface. Instead of hydroxyl groups, the characteristic bands of laccaic acid were observed on the surface of the $\mathrm{Lac}_{-} \mathrm{TiO}_{2}$ samples. The photocatalytic properties of the $\mathrm{Lac}-\mathrm{TiO}_{2}$ samples were evaluated in terms of methyl orange degradation under visible light irradiation. The $\mathrm{Lac}_{-} \mathrm{TiO}_{2}$ samples showed higher photocatalytic performance than the $\mathrm{TiO}_{2}$ sample.
\end{abstract}

Keywords: $\mathrm{TiO}_{2}$, laccaic acid-modified $\mathrm{TiO}_{2}$, impregnation method, visible photocatalyst, degradation of methyl orange

\section{Introduction}

Photocatalytic oxidation has been widely explored in terms of the removal of contaminants, including toxic organic pollutants..$^{1-3}$ In this process, various substances, including semiconductor photocatalysts, are used. ${ }^{4}$ Among all kinds of semiconductor photocatalysts, titanium dioxide $\left(\mathrm{TiO}_{2}\right)$ is widely applied in heterogeneous photocatalysis because of its low price, nontoxicity, chemical stability, and high photocatalytic activity. ${ }^{5-7}$ However, the application of

*e-mail: suwanchawalit_c@su.ac.th; suwanchawalit_c@silpakorn.edu Editor handled this article: Jaísa Fernandes Soares pure $\mathrm{TiO}_{2}$ in photocatalysis is limited due to its wide band gap $(3.2 \mathrm{eV})$ and fast recombination of photogenerated electron-hole pairs. Therefore, its activity under visible and solar light is restricted. ${ }^{8}$ To overcome these limitations, researchers developed several strategies, such as metal deposition, ${ }^{9,10}$ transition metal doping, ${ }^{11-14}$ nonmetal doping, ${ }^{15-18}$ dye-sensitized $\mathrm{TiO}_{2},{ }^{19-23}$ and coupling with other narrow-band gap semiconductors. ${ }^{24-26}$

Sensitization of $\mathrm{TiO}_{2}$ particles with dye molecules is considered an efficient method to extend their photocatalytic property into the visible region. ${ }^{27}$ Some common dye sensitizers include porphyrin, ${ }^{19}$ phthalocyanine,${ }^{21}$ and natural dyes. ${ }^{22,23}$ In general, the mechanism for the $\mathrm{TiO}_{2}$ 
photocatalyzed reaction involves the generation of electronhole pairs through light illumination. The introduction of a dye-sensitizer allows visible light absorption due to the narrower band gap of the dye molecules. The photoexcited electrons of adsorbed dyes are then injected into the conduction band $(\mathrm{CB})$ of the $\mathrm{TiO}_{2}$ photocatalyst. ${ }^{19-21}$ Hydroxyl radical $\left({ }^{\circ} \mathrm{OH}\right)$ and superoxide radical species $\left(\mathrm{O}_{2}{ }^{-}\right)$are generated on the surface of the photocatalyst and then react with organic substances, hence the degradation. ${ }^{28}$ In addition to light adsorption, the size, shape, surface area, morphological characteristics, and dimensionality of catalysts significantly affect their photocatalytic activity. ${ }^{29,30}$ The small size of $\mathrm{TiO}_{2}$ nanoparticles provides a large surface area and facilitates the charge transfer process that prevents the recombination of the electron-hole pairs. ${ }^{31-33}$

In the present work, laccaic acid-modified $\mathrm{TiO}_{2}\left(\mathrm{Lac}-\mathrm{TiO}_{2}\right)$ was prepared via an impregnation method. The effects of the amount of laccaic acid loaded on the $\mathrm{TiO}_{2}$ surface on the microstructure, optical properties, and photocatalytic activity of $\mathrm{Lac}^{-\mathrm{TiO}_{2}}$ were investigated. The synthesized Lac- $\mathrm{TiO}_{2}$ samples were characterized by X-ray diffraction analysis (XRD), field emission scanning electron microscopy (FE-SEM), X-ray photoelectron spectroscopy (XPS), UV-Vis diffused reflectance spectroscopy (DRS), Fouriertransform infrared spectroscopy (FTIR), nitrogen adsorption/ desorption, and photoluminescence (PL) spectroscopy. The photocatalytic activity of the as-prepared $\mathrm{Lac}^{-\mathrm{TiO}_{2}}$ samples was tested and compared with a pure $\mathrm{TiO}_{2}$ sample using methyl orange (MO) as a model pollutant. The hydroxyl radical $\left({ }^{\circ} \mathrm{OH}\right)$ generated during the photocatalytic reaction was examined, and a possible mechanism was proposed.

\section{Experimental}

\section{Materials}

Titanium(IV) isopropoxide was obtained from SigmaAldrich (St. Louis, Missouri, USA). Ethanol $\left(\mathrm{C}_{2} \mathrm{H}_{5} \mathrm{OH}\right)$ was purchased from Merck (Darmstadt, Germany). Methyl orange and terephthalic acid were obtained from SigmaAldrich (Saint Louis, USA). Laccaic acid solutions were prepared from the insect nest (Laccifer lacca) received from a local market in Nakhon Pathom Province, Thailand. All chemicals were of analytical grade and used as received.

\section{Preparation of $\mathrm{TiO}_{2}$}

$\mathrm{TiO}_{2}$ was prepared by the sol-gel method. First, $10.00 \mathrm{~mL}$ of titanium(IV) isopropoxide were mixed with $90.00 \mathrm{~mL}$ of ethanol. The mixture was stirred at room temperature for $24 \mathrm{~h}$ and a white $\mathrm{TiO}_{2}$ precipitate was obtained. The $\mathrm{TiO}_{2}$ precipitate was filtered and washed with deionized water. The as-prepared $\mathrm{TiO}_{2}$ powder was dried at $60{ }^{\circ} \mathrm{C}$ for $24 \mathrm{~h}$.

\section{Preparation of $\mathrm{Lac}^{-\mathrm{TiO}_{2}}$ photocatalyst}

In brief, $\mathrm{Lac}^{-\mathrm{TiO}_{2}}$ was synthesized via an impregnation method. The as-prepared $\mathrm{TiO}_{2}$ powder (0.50 g) was suspended in laccaic acid solution $(50.00 \mathrm{~mL})$ with different concentrations $(0.50,1.00,2.50$, and $5.00 \mathrm{wt} . \%)$ for $2 \mathrm{~h}$. After impregnation, the $\mathrm{Lac}-\mathrm{TiO}_{2}$ precipitate was filtered, washed with ethanol, and dried at $80^{\circ} \mathrm{C}$ for $12 \mathrm{~h}$. The catalysts synthesized from $0.5,1.0,2.5$, and $5.0 \mathrm{wt} . \%$ laccaic acid solutions were denoted as $0.5 \mathrm{Lac}-\mathrm{TiO}_{2}$, 1.0 $\mathrm{Lac}-\mathrm{TiO}_{2}, 2.5 \mathrm{Lac}-\mathrm{TiO}_{2}$, and $5.0 \mathrm{Lac}-\mathrm{TiO}_{2}$, respectively. The synthesis route of $\mathrm{Lac}_{-} \mathrm{TiO}_{2}$ is shown in Figure 1.

\section{Characterizations}

The crystal structures of the as-prepared pure $\mathrm{TiO}_{2}$ and Lac- $\mathrm{TiO}_{2}$ samples were determined through XRD recorded in a Rigaku MiniFlex II X-ray diffractometer (Singapore) with $\mathrm{Cu} \mathrm{K \alpha}$ radiation (1.5406 $\AA$ ) from $20^{\circ}$ to $80^{\circ}(2 \theta)$. Morphological characteristics were investigated via FE-SEM (TESCAN model MIRA3) (Brno, Kohoutovice, Czech Republic). Chemical compositions were collected with XPS (a voltage of $15 \mathrm{kV}$, and an emission current of $10 \mathrm{~mA}$ ) by

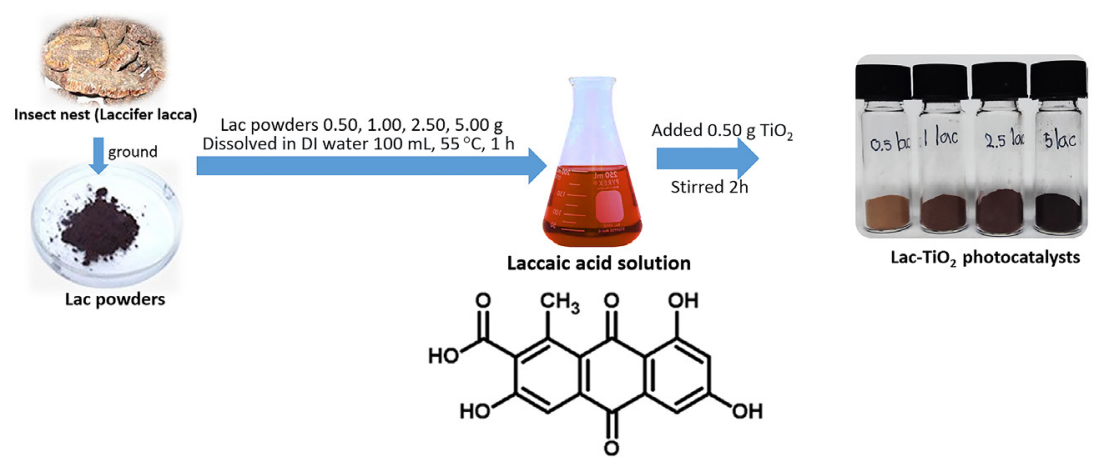

Figure 1. Synthesis route of $\mathrm{Lac}_{-} \mathrm{TiO}_{2}$ via an impregnation method. 
using a Kratos Axis Ultra spectrometer (Manchester, UK) with a monochromic $\mathrm{Al} \mathrm{K \alpha}$ source at $1486.7 \mathrm{eV}$. The optical absorption property and band gap energy were determined using a Shimadzu UV-2401 spectrophotometer (Tokyo, Japan). FTIR spectra were obtained with a PerkinElmer Spectrum Bx spectrophotometer (Waltham, Massachusetts, USA) in the range of $400-4000 \mathrm{~cm}^{-1}$ via attenuated total reflectance (ATR). The surface area and pore diameter were measured by nitrogen adsorption/desorption using a Micromeritics ASAP 2460 surface area and porosity analyzer (Norcross, GA, USA). The specific surface areas were calculated by the Brunauer-Emmett-Teller (BET) and the pore volume and pore size were calculated by the BarrettJoyner-Halenda (BJH) method.

\section{Photocatalytic experiment}

The photocatalytic activity of the as-prepared pure $\mathrm{TiO}_{2}$ and $\mathrm{Lac}_{-} \mathrm{TiO}_{2}$ was evaluated in the degradation of methyl orange (MO) under visible light. For each experiment, $0.05 \mathrm{~g}$ of the photocatalyst was suspended in $50 \mathrm{~mL}$ of MO $\left(1.0 \times 10^{-5} \mathrm{M}\right)$ in the dark for $1 \mathrm{~h}$ to allow the adsorption/ desorption equilibrium between the photocatalyst and MO. The suspension was irradiated under $18 \mathrm{~W}$ fluorescence lamps (TL-D 18 W/865 Philips tube light). ${ }^{10,34,35}$ With stirring and irradiation, $5 \mathrm{~mL}$ of the suspension was collected every $60 \mathrm{~min}$. The samples were centrifuged and the concentration of the remaining MO was analyzed using a UV-Vis spectrophotometer (Agilent HP model 8453, Victoria, Australia).

The photocatalytic efficiencies of the as-prepared pure $\mathrm{TiO}_{2}$ and $\mathrm{Lac}-\mathrm{TiO}_{2}$ were measured by the following equation:

Photocatalytic efficiency $(\%)=\frac{A_{i}-A_{t}}{A_{i}}$

where $A_{i}$ is the initial concentration of $\mathrm{MO}$, and $A_{t}$ is the concentration of $\mathrm{MO}$ at pre-determined time intervals.

The amount of the hydroxyl radical generated during the photocatalysis was determined using terephthalic acid as an ${ }^{\circ} \mathrm{OH}$ scavenger following previously described methods. ${ }^{20,36}$ The fluorescence emission spectra (excitation wavelength $315 \mathrm{~nm}$ ) were measured on a PerkinElmer LS-50B luminescence spectrometer (Beaconsfield, UK).

\section{Results and Discussion}

\section{Microstructure and optical property}

The crystal structures of pure $\mathrm{TiO}_{2}$ and $\mathrm{Lac}-\mathrm{TiO}_{2}$ were investigated by XRD. In Figure 2, all the samples showed a broad peak at $25.3^{\circ}$ indicating the low amount of the anatase phase (JCPDS No. 21-1272) mixed with an amorphous phase. ${ }^{37}$ After modification with different amounts of laccaic acid, no apparent change was observed in the XRD patterns. The XRD results suggested that the combination of $\mathrm{TiO}_{2}$ and laccaic acid did not modify the crystal structure and the size of $\mathrm{TiO}_{2}$.

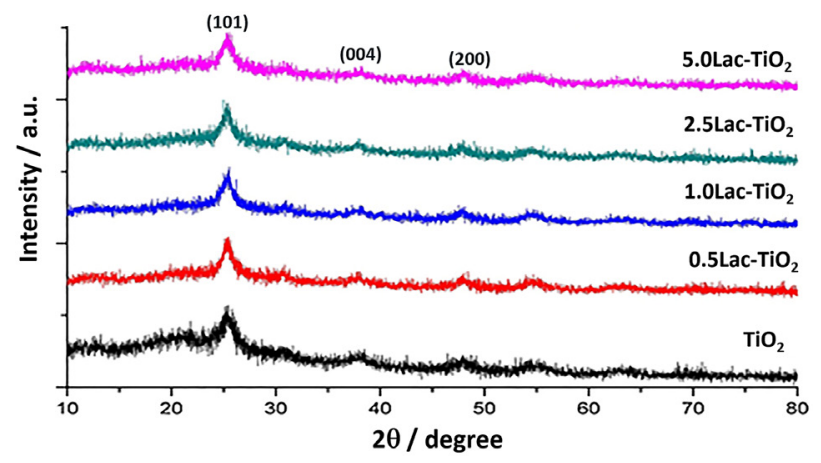

Figure 2. XRD patterns of $\mathrm{TiO}_{2}$ and $\mathrm{Lac}-\mathrm{TiO}_{2}$ samples.

The morphological characteristics of the as-prepared $\mathrm{TiO}_{2}$ and $\mathrm{Lac}^{-\mathrm{TiO}}{ }_{2}$ were observed through FE-SEM (Figure 3). Titania crystals are highly agglomerated, becoming nearly spherical with size of approximately $100-$ $200 \mathrm{~nm}$ for $\mathrm{TiO}_{2}$-supporting materials. $\mathrm{Lac}^{-\mathrm{TiO}_{2}}$ showed the same morphology as that of pure $\mathrm{TiO}_{2}$ with the $\mathrm{TiO}_{2}$ surface covered with laccaic acid molecules. The effect was more obvious when a high content of laccaic acid was present.

The surface chemical composition and bonding configuration of $\mathrm{TiO}_{2}$ and laccaic acid molecules in Lac- $\mathrm{TiO}_{2}$ samples were investigated. The full-scale XPS analysis (Figure 4a) showed a Ti2p peak at $458.5 \mathrm{eV}$, an $\mathrm{O} 1 \mathrm{~s}$ peak at $532 \mathrm{eV}$, and a $\mathrm{C} 1 \mathrm{~s}$ peak at $284.8 \mathrm{eV}$ for Lac- $\mathrm{TiO}_{2}$. This result indicated the existence of laccaic acid in $\mathrm{Lac}^{-\mathrm{TiO}_{2}}$. In Figure 4b, two individual peaks of Ti2 $p$ appeared at binding energies near 458.4 and $464.1 \mathrm{eV}$ corresponding to Ti2 $\mathrm{p}_{3 / 2}$ and $\mathrm{Ti} 2 \mathrm{p}_{1 / 2}$, respectively. This result implied a $\mathrm{Ti}^{4+}$ oxidation state of the $\mathrm{TiO}_{2}$ structure. For Figure $4 \mathrm{c}$, four peaks of O1s were observed at the binding energies of 530.34, 531.54, 532.42, and $533.39 \mathrm{eV}$. These peaks corresponded to four different types of $\mathrm{O}$ species, which were possibly $\mathrm{Ti}-\mathrm{O}$ bonds (the lattice oxygen of $\mathrm{TiO}_{2}$ ), hydroxyl ( $(\mathrm{OH})$ species, Ti-O-C bonds, and $-\mathrm{COOH}$, respectively. ${ }^{38-40}$ For C1s spectra (Figure 4d), three main separated peaks were observed at 284.9, 286.5, and $289.2 \mathrm{eV}$ and assigned to $\mathrm{C}-\mathrm{C} / \mathrm{C}=\mathrm{C}$ bond $(285.0 \mathrm{eV})$, $\mathrm{C}-\mathrm{O}$ bond $(286.6 \mathrm{eV})$, and $\mathrm{C}=\mathrm{O}(288.8 \mathrm{eV})$, respectively. ${ }^{38}$ Consistent with the data obtained from FE-SEM, the XPS results confirmed the existence of laccaic acid molecules in the $\mathrm{Lac}-\mathrm{TiO}_{2}$ samples. 

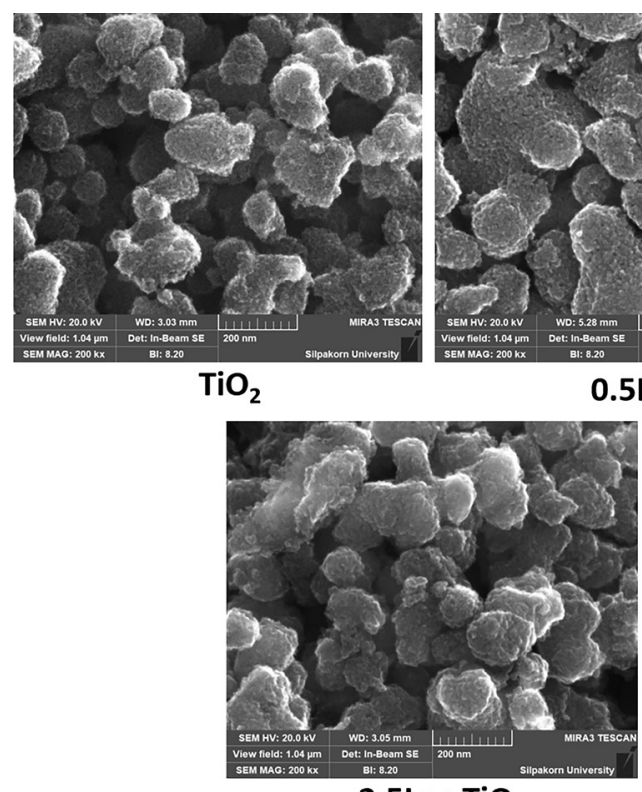

2.5 $\mathrm{Lac}^{-\mathrm{TiO}_{2}}$

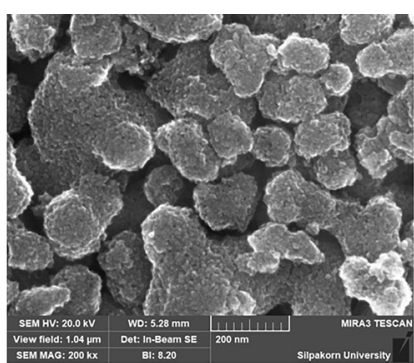

$0.5 \mathrm{Lac}^{-\mathrm{TiO}_{2}}$

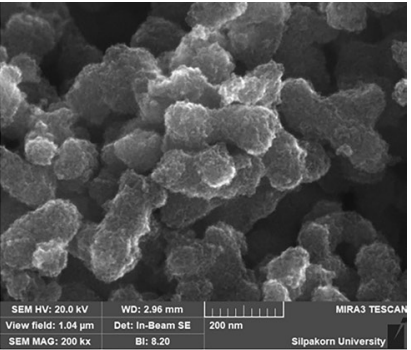

1.0Lac-TiO

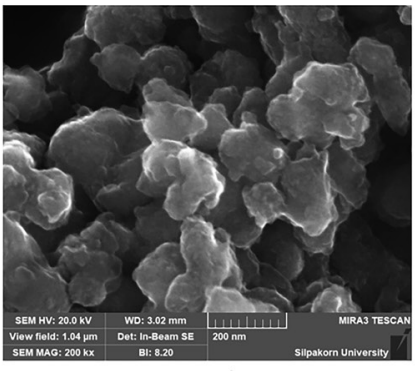

5.0 Lac-TiO

Figure 3. FE-SEM images of $\mathrm{TiO}_{2}$ and $\mathrm{Lac}-\mathrm{TiO}_{2}$ samples.
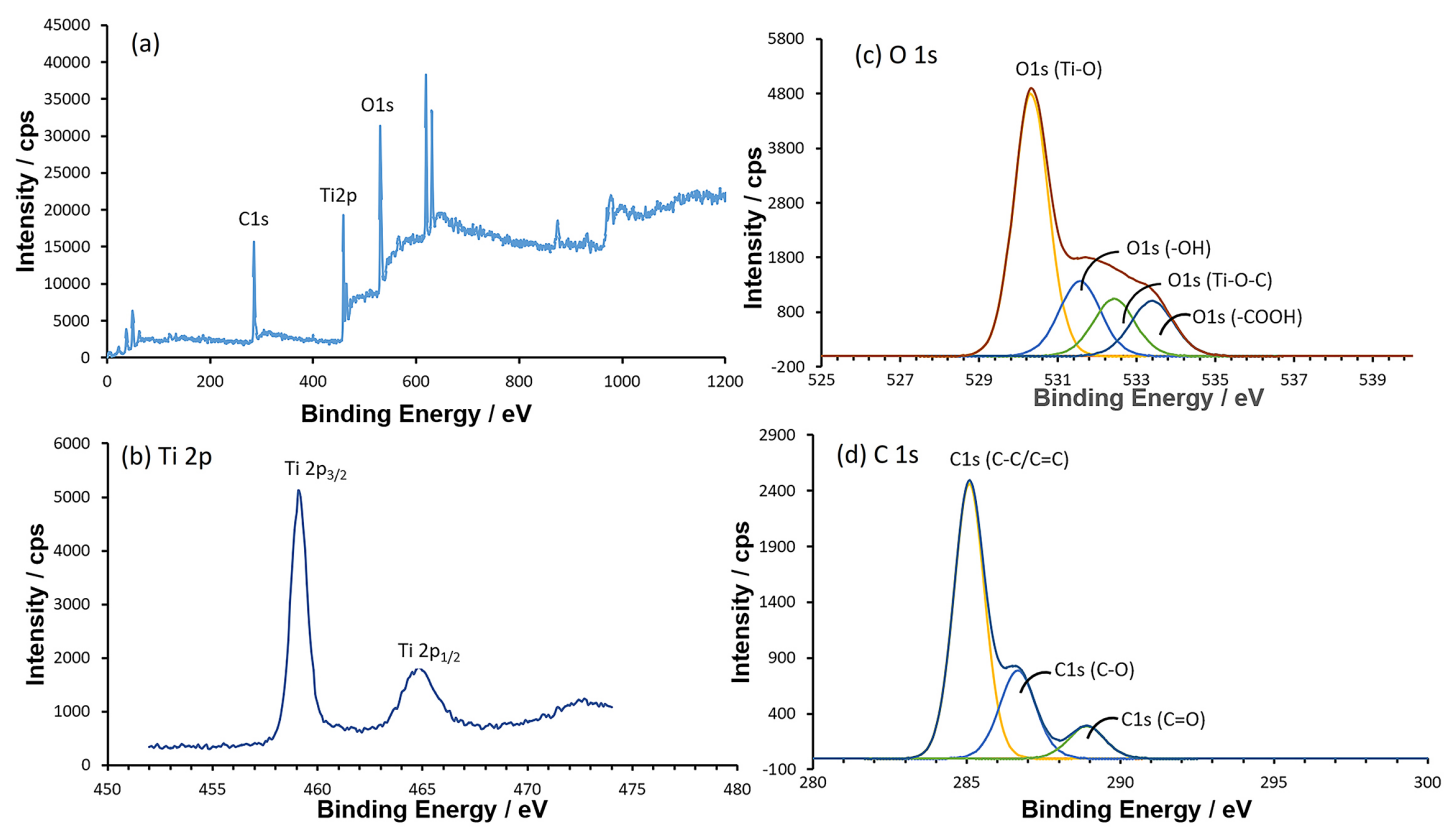

Figure 4. (a) XPS survey spectra of $\mathrm{Lac}_{-} \mathrm{TiO}_{2}$ samples and high-resolution spectra of the sample for (b) Ti2p; (c) O1s; and (d) C1s.

The optical properties of the as-prepared pure $\mathrm{TiO}_{2}$ and Lac- $\mathrm{TiO}_{2}$ samples were examined through DRS (Figure 5). The absorption band of $\mathrm{Lac}^{-\mathrm{TiO}_{2}}$ samples showed an evident redshift to the visible light region..$^{10,20}$

The band gap $\left(\mathrm{E}_{\mathrm{g}}\right)$ of the pure $\mathrm{TiO}_{2}$ and $\mathrm{Lac}-\mathrm{TiO}_{2}$ samples were determined using equation 2 :

$\mathrm{E}_{\mathrm{g}}=\frac{\mathrm{hc}}{\lambda}=\frac{1240}{\lambda}$

where $\mathrm{h}$ is Plank's constant $\left(6.626 \times 10^{-34} \mathrm{~J} \mathrm{~s}\right)$, c is the velocity of light $\left(3 \times 10^{8} \mathrm{~m} \mathrm{~s}^{-1}\right)$, and $\lambda$ is the wavelength $(\mathrm{nm})$. The calculated band gap of all samples are shown in Table 1.

The energy gap decreased from 3.26 to $2.67 \mathrm{eV}$ with increasing laccaic acid concentration. The presence of laccaic acid dye in the $\mathrm{Lac}^{-\mathrm{TiO}_{2}}$ effectively increased the absorption in the visible light region suitable for applications employing solar light.

FTIR spectra of the pure $\mathrm{TiO}_{2}$ and $\mathrm{Lac}-\mathrm{TiO}_{2}$ samples are shown in Figure 6. The broad bands at around $400-1000 \mathrm{~cm}^{-1}$ were attributed to Ti-O-Ti bond vibrations. ${ }^{10,41}$ The peaks 


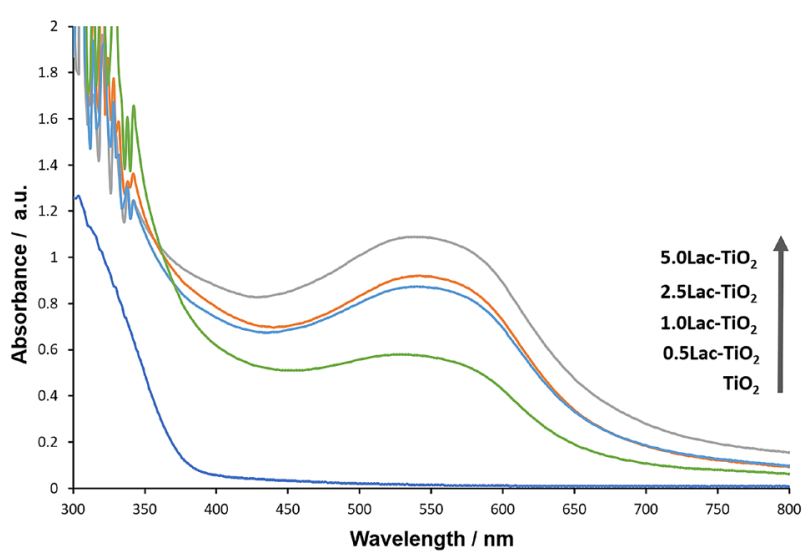

Figure 5. DRS spectra of the prepared $\mathrm{TiO}_{2}$ and $\mathrm{Lac}-\mathrm{TiO}_{2}$ samples.

Table 1. Calculated band gap of the prepared $\mathrm{TiO}_{2}$ and $\mathrm{Lac}-\mathrm{TiO}_{2}$ samples

\begin{tabular}{lc}
\hline $\mathrm{TiO}_{2}$ photocatalyst & Band gap / eV \\
\hline $\mathrm{TiO}_{2}$ & 3.26 \\
$0.5 \mathrm{Lac}-\mathrm{TiO}_{2}$ & 2.90 \\
$1.0 \mathrm{Lac}-\mathrm{TiO}_{2}$ & 2.74 \\
$2.5 \mathrm{Lac}-\mathrm{TiO}_{2}$ & 2.71 \\
$5.0 \mathrm{Lac}-\mathrm{TiO}_{2}$ & 2.67 \\
\hline
\end{tabular}

at 3000-3600 and $1640 \mathrm{~cm}^{-1}$ suggested the presence of the surface-adsorbed $\mathrm{H}_{2} \mathrm{O} .{ }^{41,42}$ Moreover, the vibration bands of Ti-O-C bond observed at 1405 and $1439 \mathrm{~cm}^{-1}$ in the Lac- $\mathrm{TiO}_{2}$ samples indicated that laccaic acid molecules were adsorbed on $\mathrm{TiO}_{2}$ surface. ${ }^{41,42}$

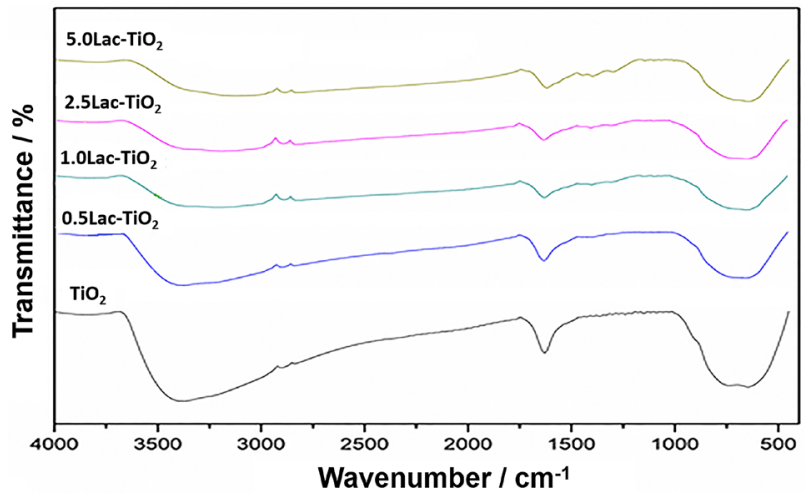

Figure 6. FTIR spectra (ATR) of $\mathrm{TiO}_{2}$ and $\mathrm{Lac}^{-\mathrm{TiO}_{2}}$ samples.

\section{Photocatalytic activity}

Typically, photocatalytic degradation involved two processes: adsorption of pollutant molecules on the catalyst and the photocatalytic process. The adsorption of MO measured in the dark of the as-prepared pure $\mathrm{TiO}_{2}$ and $\mathrm{Lac}-\mathrm{TiO}_{2}$ samples were approximately 20 and $8-10 \%$, respectively. All $\mathrm{Lac}^{-\mathrm{TiO}_{2}}$ samples showed a lower adsorption percentage than pure $\mathrm{TiO}_{2}$ possibly due to the electrostatic repulsion between the negatively charged laccaic acid and MO under the condition studied $(\mathrm{pH}=7)$. Once the adsorption/desorption equilibrium of MO had been established, the photocatalytic degradation of $\mathrm{MO}$ using the as-prepared pure $\mathrm{TiO}_{2}$ and $\mathrm{Lac}-\mathrm{TiO}_{2}$ samples was examined under visible light irradiation. The results revealed the higher photocatalytic activity of the Lac- $\mathrm{TiO}_{2}\left(0.5-2.5\right.$ wt. \%) than that of the pure $\mathrm{TiO}_{2}$ (except 5.0 $\left.\mathrm{Lac}_{-} \mathrm{TiO}_{2}\right)($ Figure 7). An optimum amount of laccaic acid on the $\mathrm{TiO}_{2}$ surface should be considered. Although more laccaic acid loading might provide a better visiblelight-harvesting ability, the amount of laccaic acid present on the surface of the photocatalyst can affect its number of active sites. In a photocatalytic process, the oxidant species $\left(\mathrm{O}_{2}{ }^{-}\right.$and $\left.{ }^{-} \mathrm{OH}\right)$ generated by the photo-excited electrons at the surface of the catalysts reacted with the adsorbed dyes, hence the active sites lied on the surface and microstructure of the catalyst. The $1.0 \mathrm{Lac}-\mathrm{TiO}_{2}$ sample showed the highest photocatalytic activity. The higher loading of laccaic acid (2.5 and 5.0 wt.\%) did not yield a better photocatalytic activity. The lower photocatalytic discoloration percentage of the higher-loading $\mathrm{Lac}-\mathrm{TiO}_{2}$ was attributable to high laccaic acid adsorbed on the surface leading to loss of active sites for generating oxidants species $\left(\mathrm{O}_{2}{ }^{--}\right.$and $\cdot \mathrm{OH}){ }^{29-32}$ The specific surface area of the as-prepared pure $\mathrm{TiO}_{2}$ and $1.0 \mathrm{Lac}-\mathrm{TiO}_{2}$ samples were measured by nitrogen adsorption-desorption isotherms. The $1.0 \mathrm{Lac}^{-\mathrm{TiO}_{2}}$ contained a greater surface area $\left(386 \mathrm{~m}^{2} \mathrm{~g}^{-1}\right.$, with pore size diameter around $26 \mathrm{~nm})$ than that of pure $\mathrm{TiO}_{2}\left(340 \mathrm{~m}^{2} \mathrm{~g}^{-1}\right.$, with pore size diameter around $30 \mathrm{~nm}$ )(Figure 8). The greater surface area of $1.0 \mathrm{Lac}-\mathrm{TiO}_{2}$ supported the greater photocatalytic activity over pure $\mathrm{TiO}_{2}$ due to more active sites available.

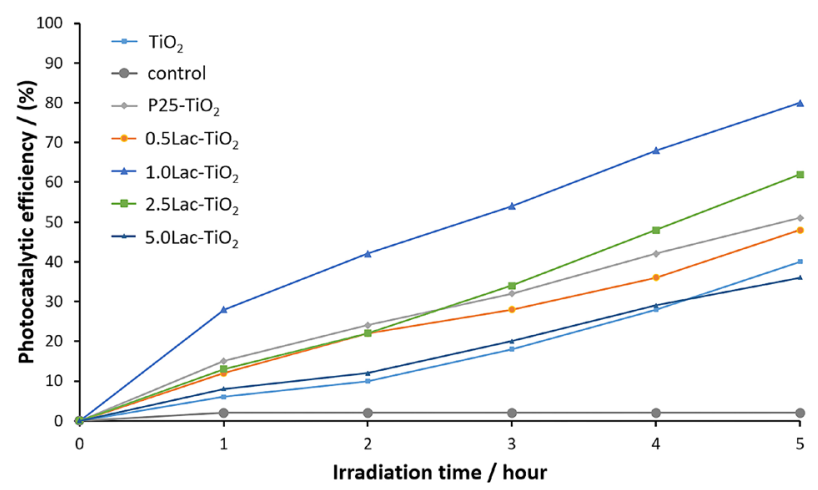

Figure 7. Comparison of the photodegradation efficiencies of MO by using $\mathrm{TiO}_{2}$ and $\mathrm{Lac}-\mathrm{TiO}_{2}$ samples under visible light irradiation.

The hydroxyl radicals $\left({ }^{\circ} \mathrm{OH}\right)$ generated by the $\mathrm{TiO}_{2}$ photocatalyst are very powerful oxidants and play a role in the degradation of organic pollutants. ${ }^{24}$ The fluorescence technique was used to monitor the ${ }^{\circ} \mathrm{OH}$ generated during 


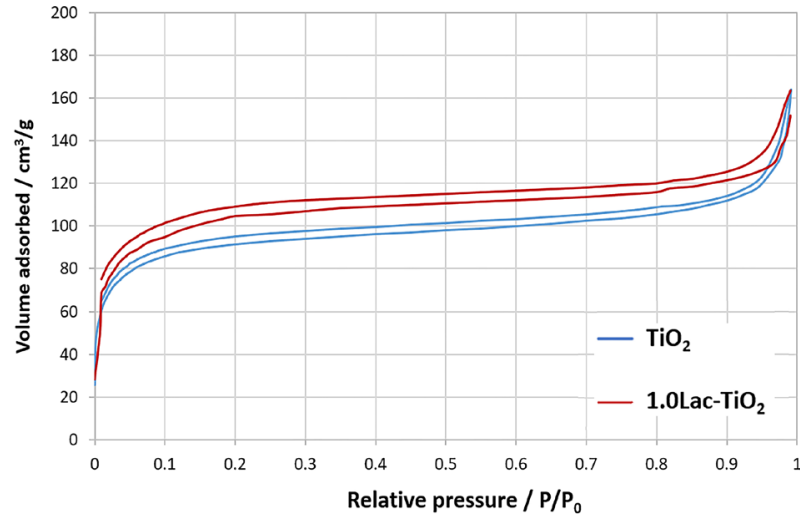

Figure 8. Nitrogen adsorption-desorption isotherms of pure $\mathrm{TiO}_{2}$ and 1.0Lac- $\mathrm{TiO}_{2}$ samples.

the photooxidation process. Terephthalic acid, an ${ }^{\circ} \mathrm{OH}$ scavenger, was transformed into 2-hydroxyterephthalic acid observed by the presence of a fluorescence emission peak at $424 \mathrm{~nm}$. The results showed that the amount of 2-hydroxyterephthalic acid was proportional to the irradiation time suggesting that ${ }^{\circ} \mathrm{OH}$ was generated during the reaction. The amount of $\mathrm{OH}$ detected from the reaction samples photocatalyzed by $1.0 \mathrm{Lac}-\mathrm{TiO}_{2}$ was greater than that of the as-prepared pure $\mathrm{TiO}_{2}$ (Figure 9), consistent with the greater photocatalytic activity of $1.0 \mathrm{Lac}-\mathrm{TiO}_{2}$.

A comparison of the photoluminescence emission spectra of the pure $\mathrm{TiO}_{2}$ sample and the $1.0 \mathrm{Lac}-\mathrm{TiO}_{2}$ sample was shown in Figure 10. Both samples showed a low emission peak around 650-665 nm (excitation wavelength $550 \mathrm{~nm}$ ). The $1.0 \mathrm{Lac}-\mathrm{TiO}_{2}$ sample exhibited a lower emission intensity than that of the pure $\mathrm{TiO}_{2}$ sample. This result was consistent with the above-mentioned result on the amount of hydroxyl radical generated since the emission arose from the electron-hole recombination. The more intense emission of the pure $\mathrm{TiO}_{2}$ sample indicated more recombination, hence less ${ }^{\circ} \mathrm{OH}$ generated. The modification of the catalyst with laccaic acid led to more efficient separation of the photogenerated electron-hole pairs, hence more ${ }^{\circ} \mathrm{OH}$ generated and higher photocatalytic efficiency.

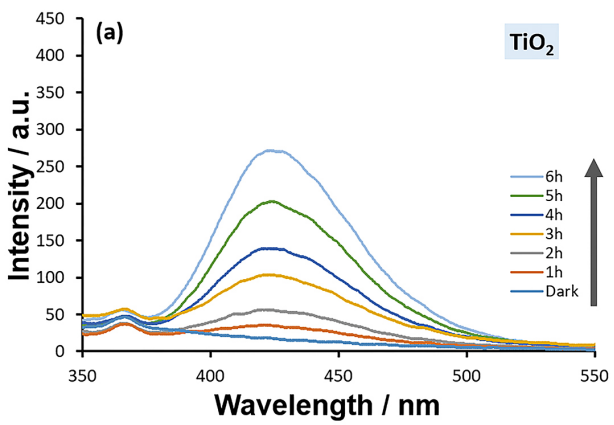

Photocatalytic activity is influenced by light adsorption, adsorption of oxygen and pollutants on the surface of the catalysts, charge separation, and electron-hole pairs recombination. A possible photocatalytic mechanism of Lac- $\mathrm{TiO}_{2}$ samples is shown in Figure 11. When illuminated with visible light, the laccaic acid electrons are excited and laccaic acid can act as an effective electron donor. The photo-excited electrons are injected into the $\mathrm{CB}$ of $\mathrm{TiO}_{2}$. These electrons $\left(\mathrm{e}_{\mathrm{CB}}{ }^{-}\left(\mathrm{TiO}_{2}\right)\right)$ subsequently reduce the $\mathrm{O}_{2}$ adsorbed on the $\mathrm{TiO}_{2}$ surface to generate superoxide anion, $\mathrm{O}_{2}{ }^{-}$which further transformed into $\mathrm{H}_{2} \mathrm{O}_{2}$ and then ${ }^{\circ} \mathrm{OH} \cdot{ }^{43,44}$ As $\cdot \mathrm{OH}$ is a very strong and highly reactive oxidant, it reacts with organic substances such as MO and degrades it. The positively charged laccaic acid (laccaic acid ${ }^{+}$) may interact with surrounding solvent molecules (S) and return to the neutral stage that will be ready for the next round of excitation under visible light irradiation ${ }^{45-47}$ The following equations represent the proposed mechanism:

laccaic acid + hv $\rightarrow$ laccaic acid*

laccaic acid* $+\mathrm{TiO}_{2} \rightarrow$ laccaic acid ${ }^{+}+\mathrm{e}_{\mathrm{CB}}{ }^{-}\left(\mathrm{TiO}_{2}\right)$

$\mathrm{O}_{2}($ ads $)+\mathrm{e}_{\mathrm{CB}} \cdot{ }^{-}\left(\mathrm{TiO}_{2}\right) \rightarrow \mathrm{O}_{2}^{\cdot-}$

$\mathrm{O}_{2}^{--}+\mathrm{H}^{+} \rightarrow \mathrm{HO}_{2}^{\cdot}$

$2 \mathrm{HO}_{2}{ }^{-}+\mathrm{H}_{2} \mathrm{O} \rightarrow 2 \mathrm{H}_{2} \mathrm{O}_{2}+{ }^{\circ} \mathrm{OH}$

$\mathrm{MO}+{ }^{\circ} \mathrm{OH} \rightarrow$ degradation products

laccaic acid $+\mathrm{S} \rightarrow$ laccaic acid $+\mathrm{S}^{+}$

$\mathrm{TiO}_{2}$ photocatalysts for the degradation of dyes in wastewater treatment

The developed photocatalyst with laccaic acid can be subjected to the discussion in comparison with other photocatalytic systems. Among various metal oxide semiconductors, $\mathrm{TiO}_{2}$ is the most frequently employed photocatalyst. Although $\mathrm{TiO}_{2}$ has good photocatalytic properties, its photocatalytic activity is limited by the tendency to have low absorption in the visible-light region and electron-hole recombination. To overcome these limitations, many methods have been developed.

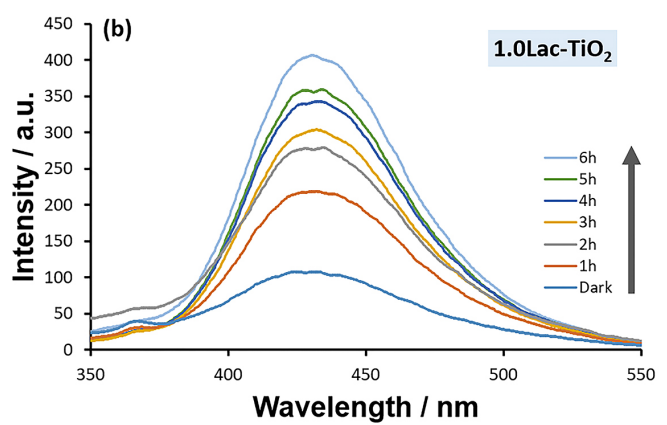

Figure 9. Comparison of the amount of ${ }^{\circ} \mathrm{OH}$ radicals produced during photocatalysis using (a) pure $\mathrm{TiO}_{2}$ sample and (b) $1.0 \mathrm{Lac}$ - $\mathrm{TiO}_{2}$ sample under visible light irradiation. 


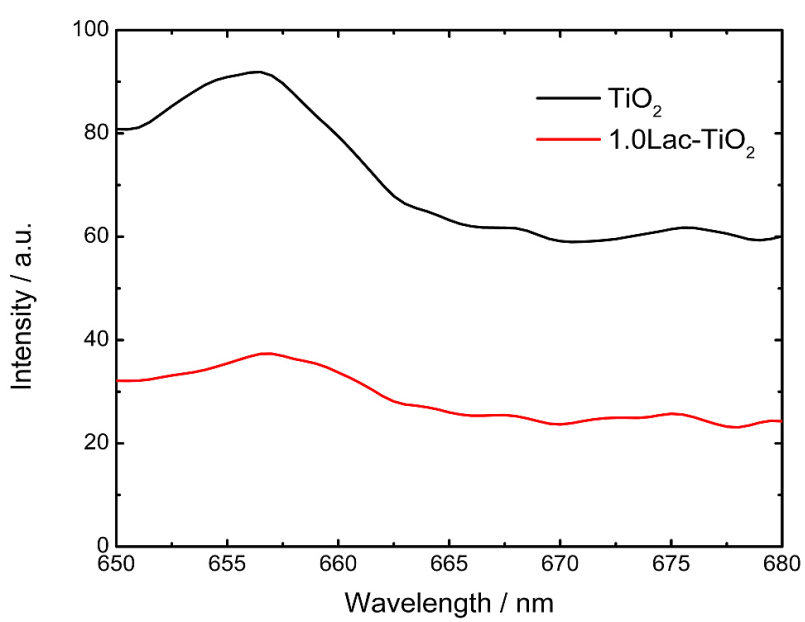

Figure 10. Photoluminescence emission spectra of pure $\mathrm{TiO}_{2}$ and 1.0Lac$\mathrm{TiO}_{2}$ samples.

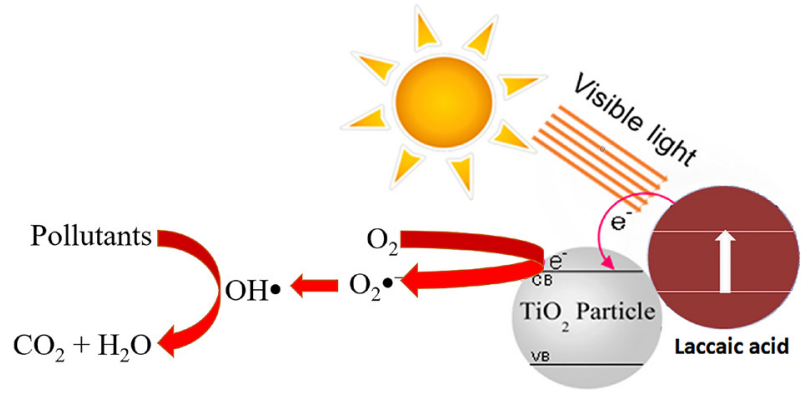

Figure 11. Schematic of the photocatalytic activity of $\mathrm{Lac}_{-} \mathrm{TiO}_{2}$ under visible light irradiation.

Table 2 shows information in association with different modifications of $\mathrm{TiO}_{2}$ such as metal doping (Co-doped
$\left.\mathrm{TiO}_{2}\right),{ }^{48}$ non-metal doping $\left(\mathrm{P}\right.$-doped $\left.\mathrm{TiO}_{2}\right),{ }^{49}$ and organic dye sensitization of $\mathrm{TiO}_{2}{ }^{50-53}$ Among these methods, dye-sensitized $\mathrm{TiO}_{2}$ has gained interest owing to its stability and improved photocatalytic efficiency. Previous studies include the usage of metalloporphyrins, ${ }^{50} \operatorname{tin}(\mathrm{IV})$ porphyrin, ${ }^{51}$ zinc phthalocyanine, ${ }^{52}$ and subphthalocyaninesensitized $\mathrm{TiO}_{2},{ }^{53}$ which exhibited an enhanced visible-light photocatalytic activity as compared to the unsensitized $\mathrm{TiO}_{2}$. Despite such interesting phenomena, the high cost and environmental toxicity of metal used in these metaldoped $\mathrm{TiO}_{2}$ and dye-sensitizers hinder their widespread use in water treatment applications. Therefore, we developed a new laccaic acid-modified $\mathrm{TiO}_{2}$ photocatalyst prepared by a simple, rapid and environmentally friendly approach. Our catalyst not only facilitates visible light absorption, providing a possibility for irradiation under solar light but also shows good photocatalytic properties. Due to those characteristics, the laccaic acid-modified $\mathrm{TiO}_{2}$ could be a good candidate as a new dye-sensitized $\mathrm{TiO}_{2}$ photocatalyst for the degradation of organic dyes in wastewater treatment.

\section{Conclusions}

Lac- $\mathrm{TiO}_{2}$ was successfully prepared via an impregnation method. Different laccaic acid concentrations were studied. The properties of $\mathrm{Lac}-\mathrm{TiO}_{2}$ photocatalysts were examined through XRD, FE-SEM, XPS, DRS, FTIR, nitrogen adsorption/desorption, and PL spectroscopy. The $\mathrm{TiO}_{2}$ phases found in the as-prepared pure $\mathrm{TiO}_{2}$ and $\mathrm{Lac}-\mathrm{TiO}_{2}$

Table 2. Preparation and photocatalytic properties of modified $\mathrm{TiO}_{2}$

\begin{tabular}{|c|c|c|c|c|c|c|}
\hline Photocatalyst & Phase & Light source & $\begin{array}{l}\text { Amount of } \\
\text { catalyst / g }\end{array}$ & Concentration of dye & Photocatalytic efficiency / \% & Reference \\
\hline Co-doped $\mathrm{TiO}_{2}$ & anatase & visible & 0.10 & $\begin{array}{c}100 \mathrm{~mL} \text { of } \mathrm{MO} \\
\left(30 \mathrm{mg} \mathrm{L}^{-1}\right)\end{array}$ & $\begin{array}{c}\text { Co-doped } \mathrm{TiO}_{2}(\text { ca. } 47 \%, 3 \mathrm{~h}) \\
\left.\mathrm{TiO}_{2} \text { (ca. 20\%, } 3 \mathrm{~h}\right)\end{array}$ & 48 \\
\hline P-doped $\mathrm{TiO}_{2}$ & anatase & visible & 0.01 & $\begin{array}{c}10 \mathrm{~mL} \text { of MO } \\
\left(20 \mathrm{mg} \mathrm{L}^{-1}\right)\end{array}$ & $\begin{array}{l}\text { P-doped } \mathrm{TiO}_{2} \\
\text { (ca. } 84 \%, 8 \mathrm{~h})\end{array}$ & 49 \\
\hline $\begin{array}{l}\text { Metalloporphyrins (MP)- } \\
\text { sensitized } \mathrm{TiO}_{2}\end{array}$ & $\begin{array}{l}75 \% \text { anatase and } \\
25 \% \text { rutile }\end{array}$ & visible & 0.04 & $\begin{array}{l}150 \mathrm{~mL} \text { of } \mathrm{MO} \\
\left(20 \mathrm{mg} \mathrm{L}^{-1}\right)\end{array}$ & 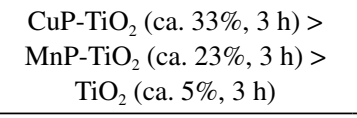 & 50 \\
\hline $\begin{array}{l}\text { Tin(IV) porphyrin-sensitized } \\
\mathrm{TiO}_{2}\end{array}$ & $\begin{array}{l}75 \% \text { anatase and } \\
25 \% \text { rutile } \\
\end{array}$ & visible & 0.01 & $\begin{array}{l}10 \mathrm{~mL} \text { of } \mathrm{MO} \\
\left(1.0 \times 10^{-4} \mathrm{M}\right) \\
\end{array}$ & $\begin{array}{c}\mathrm{SnP}-\mathrm{TiO}_{2}(\text { ca. } 85 \%, 3 \mathrm{~h})> \\
\left.\mathrm{TiO}_{2} \text { (ca. } 5 \%, 3 \mathrm{~h}\right) \\
\end{array}$ & 51 \\
\hline $\begin{array}{l}\text { Zinc phthalocyanine- } \\
\text { sensitized } \mathrm{TiO}_{2}\end{array}$ & anatase & near visible & 0.04 & $\begin{array}{l}30 \mathrm{~mL} \text { of } \mathrm{MO} \\
\left(10 \mathrm{mg} \mathrm{L}^{-1}\right)\end{array}$ & $\begin{array}{c}\mathrm{ZnPc}-\mathrm{TiO}_{2}(\mathrm{ca} .60 \%, 2.5 \mathrm{~h})> \\
\mathrm{TiO}_{2}(\text { ca. } 35 \%, 2.5 \mathrm{~h})\end{array}$ & 52 \\
\hline $\begin{array}{l}\text { Subphthalocyanine } \\
\left(\mathrm{H}_{12} \mathrm{SubPcB}-\mathrm{OPh}_{2} \mathrm{OH}\right)- \\
\text { sensitized } \mathrm{TiO}_{2}\end{array}$ & anatase & UV & 0.05 & $\begin{array}{l}50 \mathrm{~mL} \text { of } \mathrm{MO} \\
\left(10 \mathrm{mg} \mathrm{L}^{-1}\right)\end{array}$ & $\begin{array}{c}\mathrm{H}_{12} \mathrm{SubPcB}-\mathrm{OPh}_{2} \mathrm{OH}-\mathrm{TiO}_{2} \\
(\text { ca. } 96 \%, 3 \mathrm{~h})>\mathrm{TiO}_{2} \\
(\text { ca. } 29 \%, 3 \mathrm{~h})\end{array}$ & 53 \\
\hline Our system $\left(\mathrm{Lac}-\mathrm{TiO}_{2}\right)$ & $\begin{array}{l}\text { anatase mixed with } \\
\text { amorphous } \mathrm{TiO}_{2}\end{array}$ & visible & 0.05 & $\begin{array}{l}50 \mathrm{~mL} \text { of } \mathrm{MO} \\
\left(1.0 \times 10^{-5} \mathrm{M}\right)\end{array}$ & 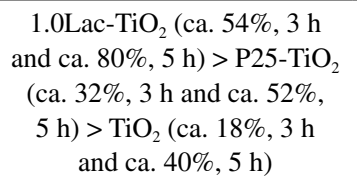 & - \\
\hline
\end{tabular}

UV: ultraviolet; MO: methyl orange. 
samples were mixtures of anatase and amorphous phases. FE-SEM images revealed that the synthesized $\mathrm{TiO}_{2}$ samples were highly agglomerated into nearly sphericallike structure. XPS data showed the presence of Ti, O, $\mathrm{C}$ elements in the $\mathrm{Lac}_{-} \mathrm{TiO}_{2}$. DRS results revealed an increase in the visible light absorption in the $\mathrm{Lac}-\mathrm{TiO}_{2}$ samples compared to that of the pure $\mathrm{TiO}_{2}$ sample. The characteristic vibrational bands of $\mathrm{Lac}_{-} \mathrm{TiO}_{2}$ were confirmed by FTIR technique. In addition, the $1.0 \mathrm{Lac}-\mathrm{TiO}_{2}$ sample has a higher specific surface area than pure $\mathrm{TiO}_{2}$ providing more active sites. The photocatalytic performance of the Lac- $\mathrm{TiO}_{2}$ samples was higher than that of the pure $\mathrm{TiO}_{2}$ sample because it could generate a higher concentration of hydroxyl radicals under visible light irradiation. Our work showed that laccaic acid potentially enhanced the photocatalytic activity of $\mathrm{TiO}_{2}$ under visible light.

\section{Acknowledgments}

This research is financially supported by Silpakorn University (Fiscal Year 2018).

\section{Author Contributions}

Cheewita Suwanchawalit was responsible for the conceptualization, methodology, investigation, writing original draft, writing review and editing, funding acquisition, resources and supervision; Montri Aiempanakit for the conceptualization, methodology, writing original draft, writing review and editing, funding acquisition, resources and supervision; Kritapas Laohhasurayotin for the conceptualization, methodology, writing original draft, writing review and editing, resources and supervision; Jariyaporn Sangkaworn for the methodology and investigation; Weerachai Sangchay for the investigation and resources; Sakchai Laksee for the investigation and resources; Nattawan Worawannotai for the writing review and editing and resources.

\section{References}

1. Hoffmann, M. R.; Martin, S. T.; Choi, W.; Bahnemann, D. W.; Chem. Rev. 1995, 95, 69

2. Herrmann, J. M.; Top. Catal. 2005, 34, 49 .

3. Ye, S.; Chen, Y.; Yao, X.; Zhang, J.; Chemosphere 2021, 273, 128503.

4. Parul; Kaur, K.; Badru, R.; Singh, P. P.; Kaushal, S.; J. Environ. Chem. Eng. 2020, 8, 103666.

5. Soundarrajan, P.; Sankarasubramanian, K.; Sethuraman, K.; Ramamurthi, K.; Chem. Eng. Commun. 2014, 16, 8756.

6. Fujishima, A.; Rao, T. N.; Tryk, D. A.; J. Photochem. Photobiol., C 2000, 1,1 .

7. Ijaz, M.; Zafar, M.; Int. J. Energy Res. 2021, 45, 3569.
8. Hashim, N.; Thakur, S.; Patang, M.; Crapulli, F.; Ray, A. K.; Environ. Technol. 2017, 38, 933.

9. Sakthivel, S.; Shankar, M. V.; Palanichamy, M.; Arabindoo, B.; Bahnemann, D. W.; Murugesan, V.; Water Res. 2004, 38, 3001.

10. Suwanchawalit, C.; Wongnawa, S.; Sriprang, P.; Meanha, P.; Ceram. Int. 2012, 38, 5201.

11. Hussain, S. T.; Siddiqa, A.; Int. J. Environ. Sci. Technol. 2011, 8,351 .

12. Hussain, S. T.; Siddiqa, A.; Siddiq, M.; Ali, S.; J. Nanoparticle Res. 2011, 13, 6517.

13. Malengreaux, C.; Pirard, S. L.; Léonard, G.; Mahy, L. G.; Herlitschke, M.; Klobes, B.; Hermann, R.; Heinrichs, B.; Bartlett, J. R.; J. Alloys Compd. 2016, 691, 726.

14. El-Bahy, Z. M.; Ismail, A. A.; Mohamed, R. M.; J. Hazard. Mater. 2009, 166, 138.

15. Gorska, P.; Zaleska, A.; Hupka; Sep. Purif. Technol. 2009, 68, 90.

16. Kosowska, B.; Mozia, S.; Moraws, A. W.; Grzmil, B.; Jamus, M.; Kalucki, K.; Sol. Cells 2005, 88, 269.

17. Zhou, P.; Yu, J.; Wang, Y.; Appl. Catal., B 2013, 142, 45.

18. Szkoda, M.; Siuzdak, K.; Lisowska-Oleksiak, A.; Phys. E 2016, $84,141$.

19. Chowdhury, P.; Moreira, J.; Gomaa, H.; Ray, A. K.; Ind. Eng. Chem. Res. 2012, 51, 4523.

20. Aiempanakit, M.; Tabtimsri, T.; Triamnak, N.; Suwanchawalit, C.; Int. J. Electrochem. Sci. 2019, 14, 1954.

21. Huang, C.; Lv, Y.; Zhou, Q.; Kang, S. Z.; Li, X. Q.; Mu, J.; Ceram. Int. 2014, 40, 7093.

22. Goulart, S.; Nieves, L. J. J.; Dal Bo', A. J.; Bernardin, A. M.; Dyes Pigm. 2020, 182, 108654

23. Hug, H.; Bader, M.; Mair, P.; Glatzel, T.; Appl. Energy 2014, 115,216

24. Senevirathna, M. K. I.; Pitigala, P.; Tennakone, K.; J. Photochem. Photobiol., A 2005, 171, 257.

25. Sun, W. T.; Yu, Y.; Pan, H. Y.; Gao, X. F.; Chen, Q.; Peng, L. M.; J. Am. Chem. Soc. 2008, 130, 1124.

26. Mohini, R.; Lakshminarasimhan, N.; Mater. Res. Bull. 2016, 76,370 .

27. Mustafa, M. N.; Sulaiman, Y.; Sol. Energy 2021, 215, 26.

28. Muscetta, M.; Russo, D.; Catalysts 2021, 11, 834.

29. Youssef, Z.; Arnoux, P.; Colombeau, L.; Toufaily, J.; Hamieh, T.; Frochot, C.; Roques-Carmes, T.; J. Photochem. Photobiol., A 2018, 356, 177 .

30. Jiang, G.; Geng, K.; Wu, Y.; Han, Y.; Shen, X.; Appl. Catal., B 2018, 227, 366.

31. Hsiao, Y. C.; Wu, T. F.; Wang, Y. S.; Hu, C. C.; Huang, C.; Appl. Catal., B 2014, 148-149, 250.

32. Youssef, Z.; Colombeau, L.; Yesmurzayeva, N.; Baros, F.; Vanderesse, R.; Hamieh, T.; Toufaily, J.; Frochot, C.; RoquesCarmes, T.; Acherar, S.; Dyes Pigm. 2018, 159, 49.

33. Wang, H.; Wu, Y.; Xu, B. Q.; Appl. Catal., B 2005, 59, 139. 
34. Suwanchawalit, C.; Buddee, S.; Wongnawa, S.; J. Environ. Sci. 2017, 55, 257.

35. Buddee, S.; Suwanchawalit, C.; Wongnawa, S.; Dig. J. Nanomater. Biostructures 2018, 12, 829.

36. Mehraj, O.; Mir, N. A.; Pirzada, B. M.; Sabir, S.; Muneer, M.; J. Mol. Catal., A 2014, 395, 16.

37. Pookmaneea, P.; Phanichphant, S.; J. Ceram. Process. Res. 2009, 10, 167.

38. Liu, R.; Li, H.; Duan, L.; Shen, H.; Zhang, Y.; Zhao, X.; Ceram. Int. 2017, 43, 8648.

39. Kruse, N.; Chenakin, S.; Appl. Catal., A 2011, 391, 367.

40. Yu, X.; Liu, J.; Yu, Y.; Zuo, S.; Li, B.; Carbon 2014, 68, 718.

41. Choi, S. K.; Yang, H. S.; Kim, J. H.; Park, H.; Appl. Catal., B 2012, 121-122, 206.

42. Vasimalai, N.; Vilas-Boas, V.; Gallo, J.; Cerqueira, M. F.; Menéndez-Miranda, M.; Costa-Fernández, J. M.; Diéguez, L.; Espiña, B.; Fernández-Argüelles, M. T.; Beilstein J. Nanotechnol. 2018, 9, 530.

43. Chatterjee, D.; Dasgupta, S.; Rao, N. N.; Sol. Energy Mater. Sol. Cells 2006, 90, 1013.
44. Zhang, X.; Wang, Y.; Hou, F.; Li, H.; Yang, Y.; Zhang, X.; Yang, Y.; Wang, Y.; Appl. Surf. Sci. 2017, 391, 476.

45. Ganesh, T.; Kim, J. H.; Yoon, S. J.; Kil, B. H.; Maldar, N. N.; Han, J. W.; Han, S. H.; Mater. Chem. Phys. 2010, 123, 62.

46. Buddee, S.; Wongnawa, S.; Sriprang, P.; Sriwong, C.; J. Nanopart. Res. 2014, 16, 2336.

47. Dil, M. A.; Haghighatzadeh, A.; Mazinani, B.; Bull. Mater. Sci. 2019, 42, 248.

48. Mostaghni, F.; Abed, Y.; Mater. Res. 2016, 19, 741.

49. Xia, Y.; Jiang, Y.; Li, F.; Xia, M.; Xue, B.; Li, Y.; Appl. Surf. Sci. 2014, 289, 306.

50. Zhou, X.-T.; Ji, H.-B.; Huang, X.-J.; Molecules 2012, 17, 1149.

51. Zhang, J.; Zhang, L.; Li, X.; Kang, S.-Z.; Mu, J.; J. Dispersion Sci. Technol. 2011, 32, 943.

52. Altın, İ.; Sökmen, M.; Bıyıklığlu, Z.; Desalin. Water Treat. 2016, 57, 16196.

53. Yang, L.; Zhang, B.; Li, Z.; Wang, C.; Jiao, L.; Wang, B.; Wang, Y.; Ma, H.; Ma, X.; Appl. Organomet. Chem. 2021, 35, e6270.

Submitted: August 12, 2021

Published online: January 7, 2022 